\title{
Geoscientific research in the Wadden Sea region (editorial)
}

\section{J.M. Verweij ${ }^{*}$ \&. Schokker}

TN0 - Geological Survey of the Netherlands. P0 Box 80015, NL-3508 TA Utrecht, the Netherlands.

* Corresponding author. Email: hanneke.verweij@tno.nl

The Wadden Sea system along the south-eastern coast of the North Sea is one of the world's largest uninterrupted systems of barrier islands, tidal channels, tidal flats and salt marshes, where natural processes continue to function largely undisturbed. This highly dynamic system stretches over three countries from Den Helder in the Netherlands, through Germany, to Blåvandshuk in Denmark (Fig. 1). The Dutch and German parts of the Wadden Sea have been designated as a UNESCO World Heritage Site in 2009 in recognition of the unique biotic and abiotic natural features and active processes.

Geologically, the Wadden Sea system is a very young system. It evolved in the Holocene in relation to the continuous post-glacial sea-level rise under temperate climate conditions (0ost, 1995). During its development, the vertical and lateral extent of the Wadden

A
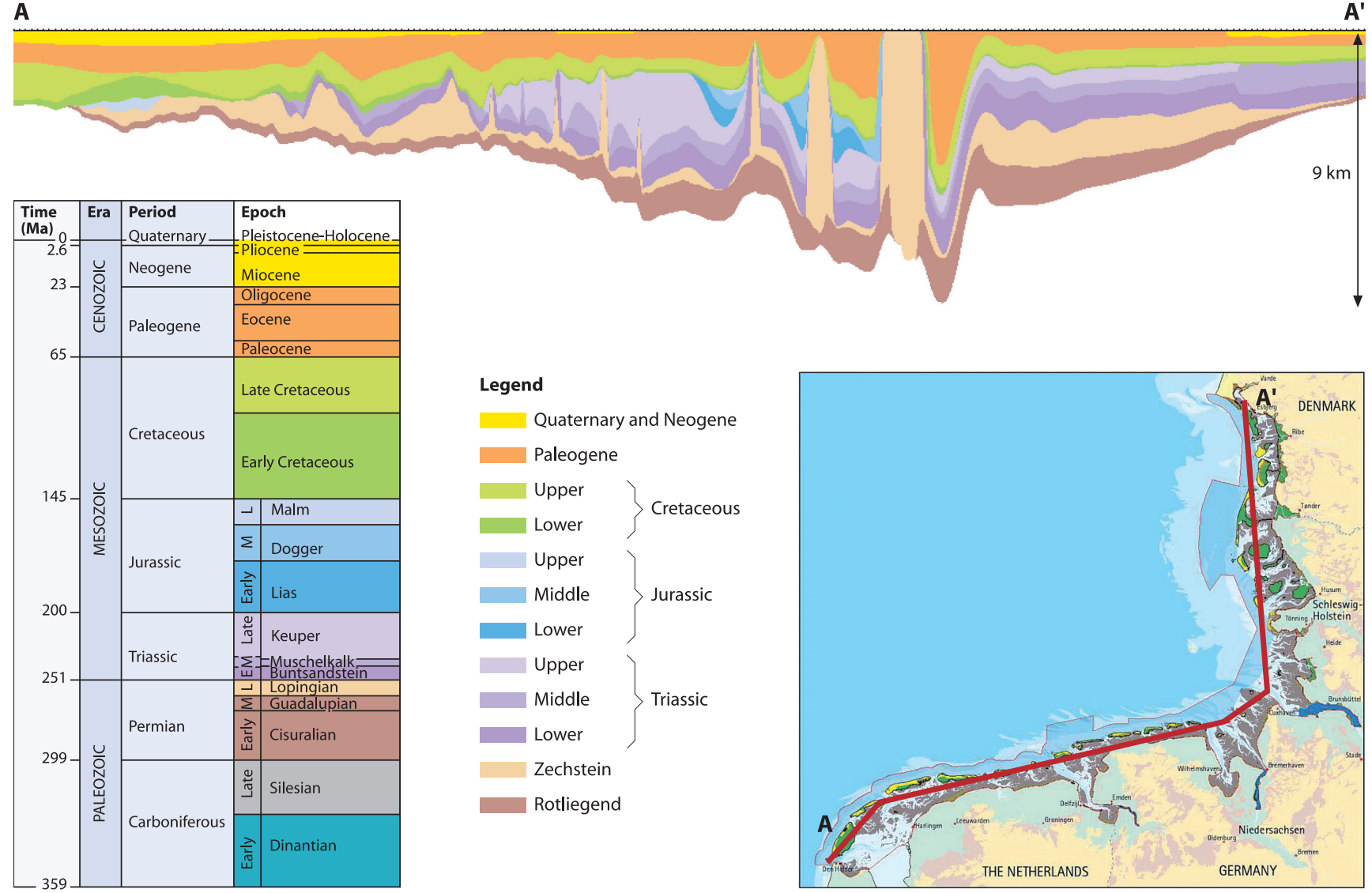

Fig. 1. Cross-section through the Wadden Sea Region from Den Helder in the Netherlands to Blåvandshuk in Denmark. The cross-section shows the great spatial variations in stratigraphic build-up and structural framework of the subsurface of the Wadden Sea Region. These variations reflect the great spatial variation in geological histories and past and ongoing geological processes (cross-section is $2 D$ extraction from the Southern Permian Basin Atlas; Doornenbal \& Stevenson, 2010). 
Sea system shifted in space. The current conditions and characteristics of this dynamic natural system represent just one moment in time during an on-going development (Kroonenberg \& Speelman, 2011). A large part of the bordering coastal lowlands that are at present safeguarded by dikes and dams are characterised by Holocene coastal deposits in the shallow subsurface and can thus be regarded as an integral part of the Wadden Sea natural sedimentary system (Fig. 2). The current conditions and characteristics are the cumulative result of processes deep in the earth, near and at the surface of the earth and in the atmosphere, which take place on different time and spatial scales. From the Middle Ages onward, the Wadden Sea system has been increasingly influenced by human activities, such as dike building, land reclamation and exploitation of peat. Today, the subsurface of the Wadden Sea region offers a variety of possible uses that the islands and coastal provinces can help to become more self-reliant with regard to groundwater and geo-energy and to achieve sustainability. Current uses include the extraction of natural resources, such as

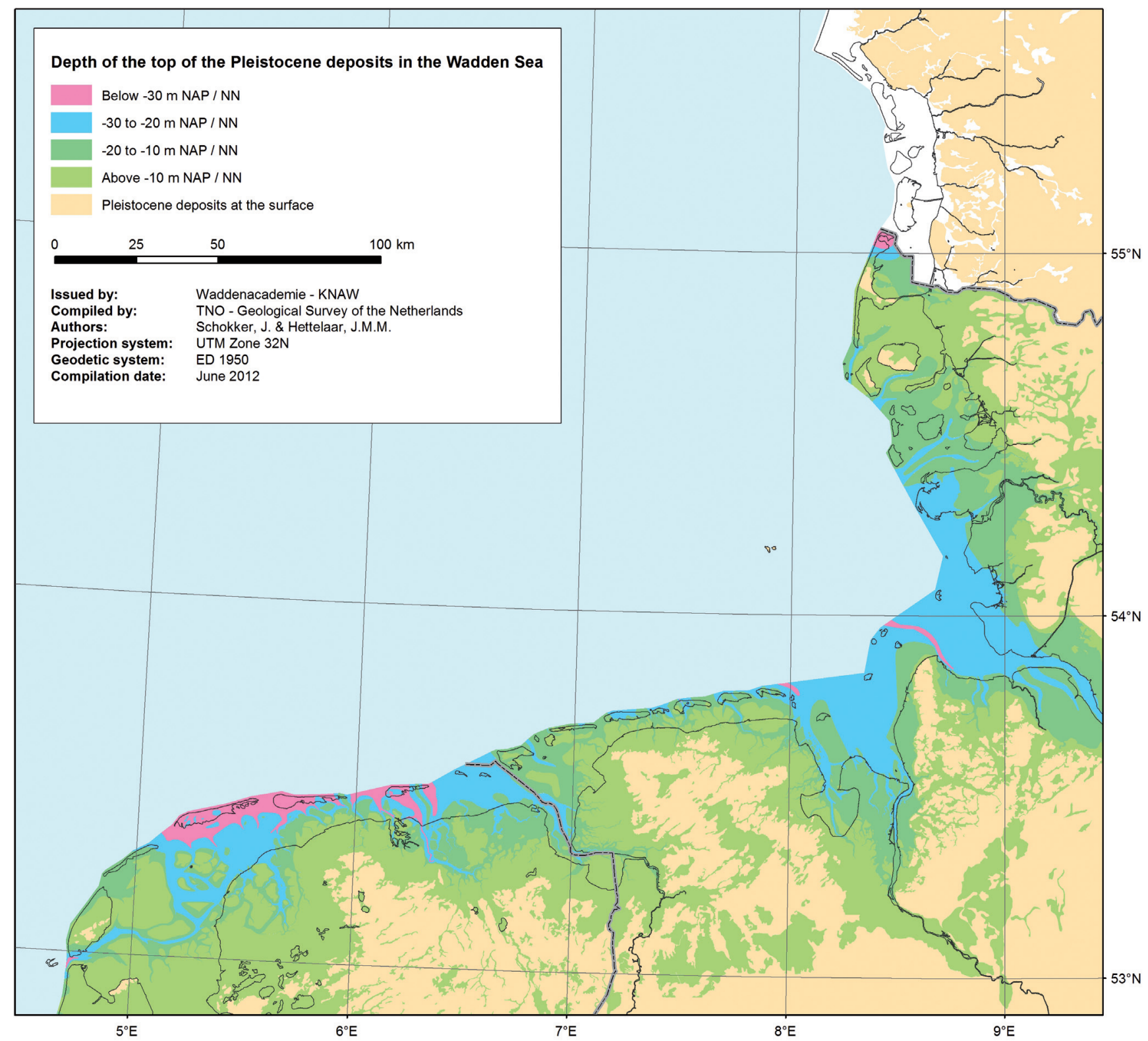

Figure 2. Compilation map showing the actual depth of the top of the Pleistocene deposits in the Dutch and German sectors of the Wadden Sea. It thus presents both the depth of the base and the maximum landward sedimentary extent of the Wadden Sea natural coastal system. At the end of the Pleistocene, the region was characterised by the existence of several prominent SE-NW oriented elevated areas separated by deeply incised fluvial valley systems. In the course of the Holocene, this spatial pattern was modified as a result of the interaction of various time-dependent and space-dependent processes: deep and shallow tectonic movements, glacio-isostatic adjustments, eustatic sea-level rise, coastal and shallow marine sedimentary processes and man-induced changes in the natural system. The map has been compiled, based on various published data sources: Ahrendt (2007), BGR (1973-2012), LBEG (2000-2012), Vos \& Bazelmans (2011), Vos \& Knol (2005) and Wiersma et al. (2009). 
groundwater, salt and natural gas, the storage of gas and brines, and exchange of heat and cold. Multiple use of the subsurface from shallow to great depths increases rapidly in the Netherlands and also in the Wadden Sea area. Current and future use of the subsurface impacts rock and fluid properties and processes in the subsurface and their effects continue to the surface (land movement, seismicity) on different time and spatial scales.

The absolute and relative contributions of the different natural processes and human activities on current and future conditions and characteristics of the Wadden Sea system are however still poorly understood.

The Wadden Academy of the Royal Netherlands Academy of Arts and Sciences states in its 'Integrated Research Agenda' (Kabat et al., 2009) that new knowledge and expertise concerning the natural, economic and socio-cultural condition and development of the Wadden Sea area is required for devising its sustainable future. This Integrated Research Agenda concerns primarily the Dutch part of the Wadden Sea area. It is built on various position papers; one of them is the position paper on geosciences (Speelman et al., 2009). The 'Integrated Research Agenda' also proposes a number of integrated research programs. A detailed plan for an integrated research program, including geoscientific research, is 'Knowledge of the past for a sustainable future of the Wadden' (Verweij et al., 2010). The position paper on geosciences provides an overview of the state of knowledge, and identifies research questions and gaps in knowledge with regard to three related themes concerning the geological development of the Wadden Sea area in time and space. The geoscientific themes are 'Subsurface of the Wadden Sea Region', 'Evolution of the Wadden Sea Region', and 'Morphodynamics of the Wadden Sea'. The focusses of the theme 'Subsurface of the Wadden Sea Region' is on the geological buildup and structure (Fig. 1), the physico-chemical properties of rocks, faults and fluids, processes on geological time and spatial scale, and the relatively fast-moving processes in the subsurface that are connected to its use. The theme 'Evolution of the Wadden Sea Region' mainly concerns the natural development and dynamics of the Wadden Sea Region over time scales ranging from decades to thousands of years, including the anthropogenic impact of especially the last two centuries. The theme 'Morphodynamics of the Wadden Sea' focusses on short-time dynamics and relates to natural and human-influenced processes/ changes that take place on an 'engineering' time scale (from seasons to decades).

This special issue presents results of recent and ongoing geoscientific research in the Dutch part of the Wadden Sea Region on each of the three themes:

Elias et al. (this issue) present a quantitative analysis of the morphodynamic evolution of the Dutch Wadden Sea under rising sea level and human constraint. The analysis is based on nearly 100 years of bathymetric measurements and includes the construction of yearly bathymetric maps followed by calculation of sediment-erosion values. The sediment budget and morphological analyses are presented for the main inlet systems: Texel and Vlie, Eierlandse Gat, Ameland and Frisian Inlets, and Groninger Wad and EmsDollard estuary. The authors provide interpretations of the observed variations in sediment budget and discuss implications of their analyses for the future of the Wadden Sea.

Kleinhans et al. (this issue) use the Wadden Sea as a natural example of a complex tidal system. In their study, they present a novel experimental setup for the creation of tidal systems in the laboratory. Unlike field studies and numerical modelling studies, laboratory experiments enable to study the morphodynamics of these systems under constant forcing and long-term evolution. Focus is on possible scale effects and whether morphological equilibrium of these systems can be reached. The study discusses the possible benefits and limitations of the experiments and suggests how to use these when studying systems under changing forcing, like in a sea-level change scenario.

In their study, Van der Vegt \& Hoekstra (this issue) focus on one, small tidal inlet system: the Slufter on the island of Texel. This shallow, secondary inlet is studied by several methods on both longer and shorter time scales. Aerial photographs and crossshore transects provided observational time series spanning more than half a century. An intensive field campaign focussed on processes and morphological changes during both fair weather and storm events. In their discussion, the dynamics of the Slufter tidal inlet are compared to the dynamics of neighbouring morphological elements in the Wadden Sea tidal system.

Paap et al. (this issue) use shallow seismics to arrive at a better understanding of the subsurface near the Afsluitdijk. In a 'one-sweep-survey', the authors acquired data with three different seismic systems. The geological interpretation of the seismic facies enabled them to derive information from the upper $60 \mathrm{~m}$ of the subsurface, which includes deposits of Holocene channel systems related to the Zuiderzee. Results are compared to a current hydrogeological model of the area and implications for future management and renovation works of the Afsluitdijk are deducted.

In a very elegant paper, Ruessink et al. (this issue) focus on coastal safety along dune coasts. They demonstrate that the equilibrium dune-erosion model that is currently used along the Dutch coast to assess the strength of the most seaward dune row to withstand a storm (DUROS+) is not fit for application in the complex setting of the Wadden islands. For this area, the authors propose a shift from the present model to a process-based dune-erosion model that aims to predict the interaction between water motion, sand suspension and transport, and the bathymetry. Based on the results from field studies and laboratory measurements, they state that several issues need to be addressed before such a model is able to adequately predict dune erosion. 
Pauw et al. (this issue) investigated salt water intrusion and salinisation of groundwater flow systems on the island of Texel and in the area of Barradeel, using numerical modelling code MOCDENSE3D. The Texel study aims to quantify the extent of salt water intrusion and salinisation due to future rise of sea level. The Barradeel modelling study focussed on the effects of salt solution mining on land subsidence and salinisation. Pauw et al. also investigated the influence of counter-measures to mitigate salinisation in the future and discuss the results.

De Waal et al. (this issue) address the legal, technical and organisational aspects of subsidence management in the Netherlands, including the concept of 'effective subsidence capacity' and the 'Hand on the Tap' control loop. The effective subsidence capacity, the maximum human-induced subsidence that an affected area can robustly sustain, and the 'Hand on the Tap' approach were originally developed for the Wadden Sea area in relation with gas production. The authors provide detailed information on the background and current application of these approaches in the Wadden Sea.

This special issue of the Netherlands Journal of Geosciences is available for participants of the $13^{\text {th }}$ International Scientific Wadden Sea Symposium (21-23 November 2012) in Leeuwarden, the Netherlands. National and international research in the trilateral Wadden Sea region is presented during the symposium. The papers in the special issue show the progress in geoscientific research in the Dutch part of the Wadden Sea region and thus provide input for planning of - trilateral - geoscientific research programs.

\section{References}

Ahrendt, K., 2007. Vergangenheit und Zukunft des nordfriesischen Wattenmeeres. In: Gönnert, G., Pflüger. B. \& Bremer, J.-A. (eds): Von der Geoarchäologie über die Küstendynamik zum Küstenzonenmanagement. Coastline Reports 9: 45-57.

BGR, 1973-2012. Geologische Übersichtskarte der Bundesrepublik Deutschland 1:200,000 (GÜK200). Bundesanstalt für Bodenforschung \& Bundesanstalt für Geowissenschaften und Rohstoffe, Hannover. (various map sheets).

De Waal, J.A., Roest, J.P.A., Fokker, P.A., Kroon, I.C., Breunese, J.N., MuntendamBos, A.G., Oost, A.P. \& Van Wirdum, G., 2012 (this issue). The effective subsidence capacity concept: How to assure that subsidence in the Wadden Sea remains within defined limits? Netherlands Journal of Geosciences 91-3: 385-399.

Doornenbal, J.C. \& Stevenson, A.G. (eds), 2010. Petroleum Geological Atlas of the Southern Permian Basin Area. EAGE Publications, Houten, the Netherlands, $352 \mathrm{pp}$.

Elias, E.P.L., Van der Spek, A.J.F., Wang, Z.B. \& De Ronde, J., 2012 (this issue). Morphodynamic development and sediment budget of the Dutch Wadden Sea over the last century. Netherlands Journal of Geosciences 91: 293-310.

Kabat, P., Bazelmans, J., Van Dijk, J., Herman, P.M.J., Speelman, H., Deen, N.R.J. \& Hutjes, R.W.A. (eds), 2009. Knowledge for a sustainable future of the Wadden. Integrated research agenda of the Wadden Academy, Wadden Academy-KNAW, Leeuwarden, the Netherlands, 124 p. (available at: www.waddenacademie. knaw.nl).

Kleinhans, M.G., Van der Vegt, M., Terwisscha van Scheltinga, R., Baar, A.W. \& Markies, H., 2012 (this issue). Turning the tide: experimental creation of tidal channel networks and ebb deltas. Netherlands Journal of Geosciences 91: 311-323.

Kroonenberg, S. \& Speelman, H., 2010. Development of the Wadden area in time and space. Oral presentation at the 5th Symposium of the Waddenacademy: 'Towards a Trilateral Research Agenda', 8-10 December 2010, Leeuwarden, the Netherlands. (pdf and video available at: www.waddenacademie.knaw.nl).

LBEG, 2000-2012. Geologische Küstenkarte von Niedersachsen 1:25,000 - Relief der Holozänbasis (GHBK25). Landesamt für Bergbau, Energie und Geologie, Hannover. (various map sheets).

Oost, A.P., 1995. Dynamics and sedimentary development of the Dutch Wadden Sea with emphasis on the Frisian Inlet, A study of barrier islands, ebb-tidal deltas, inlets and drainage basins, Doctoral thesis, Utrecht University, 455 pp.
Paap, B.F., Dubelaar, C.W., Gunnink, J.L. \& Oost, A.P., 2012 (this issue). Unravelling the shallow geology of the western Wadden Sea using highresolution seismics. Netherlands Journal of Geosciences 91: 341-355.

Pauw, P., De Louw, P.G.B. \& Oude Essink, G.H.P., 2012 (this issue). Groundwater salinisation in the Wadden Sea area of the Netherlands: quantifying the effects of climate change, sea-level rise and anthropogenic interferences. Netherlands Journal of Geosciences 91: 373-383.

Ruessink, B.G., Boers, M., Van Geer, P.F.C., De Bakker, A.T.M., Pieterse, A., Grasso, F. \& De Winter, R.C., 2012 (this issue). Towards a prcess-based model to predict dune erosion along the Dutch Wadden coast. Netherlands Journal of Geosciences 91: 357-372.

Speelman, H., Oost, A., Verweij, H. \& Wang, Z.B., 2009. De ontwikkeling van het Waddengebied in tijd en ruimte. Position paper Geowetenschap, 104 pp. (available at: www.waddenacademie.knaw.nl).

Van der Vegt, M. \& Hoekstra, P., 2012 (this issue). Morphodynamics of a stormdominated, shallow tidal inlet: the Slufter, the Netherlands. Netherlands Journal of Geosciences 91: 325-339.

Verweij, H., De Boer, P., Kroonenberg, S., Mol, H., Speelman, H. \& Spek, Th., 2010. Kennis van het Verleden voor een Duurzame Toekomst van de Wadden. Uitwerking kennis- en onderzoekprogramma A 'Verleden Wadden: de reconstructie van de ontwikkeling van het waddengebied' van de Integrale Kennisagenda Waddenacademie 2009, 26 pp. (available at: www.waddenacademie. knaw.nl).

Vos, P.C. \& Bazelmans, J., 2011. Hoe zijn de kaarten tot stand gekomen? In: Vos, P.C., Bazelmans, J., Weerts, H.J.T. \& Van der Meulen, M.J. (eds): Atlas van Nederland in het Holoceen. Bert Bakker, Amsterdam: 29-32.

Vos, P.C. \& Knol, E., 2005. Wierden ontstaan in een dynamisch getijdelandschap. In: Knol, E., Bardet, A.C. \& Prummel, W. (eds): Professor Van Giffen en het geheim van de wierden. Groninger Museum, Groningen: 119-135.

Wiersma, A.P., Oost, A.P., Van den Berg, M.W., Vos, P.C., Marges, V. \& De Vries, S., 2009. Geomorphology. Thematic Report 9. In: Marencic, H. \& De Vlas, J. (eds): Quality Status Report 2009. Wadden Sea Ecosystems 25. Common Wadden Sea Secretariat, Wilhelmshaven. 